o. Tomasz Gałkowski CP

Ius Matrimoniale

30 (2019) $\mathrm{nr} 3$

DOI:10.21697/im.2019.30.3.02

Wydział Prawa Kanonicznego UKSW

ORCID 0000-0001-9166-9516

\title{
Papież Franciszek jako sędzia w procesie o stwierdzenie nieważności małżeństwa
}

Treść: Wstęp. 1. Biskup diecezjalny jako sędzia i pasterz. 2. Autor wyroku. 3. Aspekty procesowe papieskiego wyroku. 4. Aspekty materialne papieskiego wyroku. 5. Uwagi do wyroku.

\section{Wstęp}

13 lipca 2017 r., półtora roku po wejściu w życie papieskich przepisów reformujących przebieg procesu o stwierdzenie nieważności małżeństwa ${ }^{1}$, papież Franciszek jako biskup diecezji rzymskiej wydał wyrok stwierdzający nieważność małżeństwa². Działalność Franciszka jest zastosowaniem przepisów przez niego ustalonych jako najwyższego prawodawcy w Kościele katolickim. Skorzystał z możliwości przysługującej każdemu biskupowi diecezjalnemu rozstrzygnięcia kwestii nieważności małżeństwa na drodze procesu skróconego przed biskupem. Tym samym „uczynił siebie konkretnym przykładem dla

1 Franciszek, Mitis Iudex Dominus Iesus (tekst łacińsko - polski), Tarnów 2015. Nowe przepisy zaczęły obowiązywać 8 grudnia 2015 r. [dalej: MIDI].

2 Coram Francesco, Sent. In procesu breviore 13.07.2017 r. ob. exclusum bonum sacramenti ex parte mulieris actricis (can. 1101, \$2 CIC), w: P.V. Pinto, Małżeństwo i rodzina na synodalnej ścieżce papieża Franciszka, Città di Castello PG 2019, s. 217-221 (w dalszej części opracowania cytuję wyrok wydany przez Franciszka, podając kolejne numery jego treści). 
biskupów zastosowania reformy osądzając i podpisując osobiście jeden wyrok w procesie skróconym. Ten fakt nie miał miejsca od wieków ${ }^{3 "}$. Praktyczna realizacja założeń Franciszka dotyczących procesu o stwierdzenie nieważności małżeństwa wraz z treścią wyroku jest przedmiotem analizy niniejszego opracowania.

W literaturze kanonistycznej, zwłaszcza, ale nie tylko w periodykach, które programowo zajmują się tematyką prawa małżeńskiego materialnego i formalnego, analiza i omówienie wyroków wydawanych przez sądy kościelne jest powszechnie obecna. Nieocenioną wartością są publikowane wyroki Roty Rzymskiej oraz biorące je za temat analiz kolejne opracowania ${ }^{4}$. Nie mniejszą popularnością są wyroki wydawane przez poszczególne trybunały diecezjalne czy międzydiecezjalne, do których komentarze pojawiają się w kanonistycznej literaturze ${ }^{5}$. Treść wyroków jest również przedmiotem wielu prac doktorskich czy magisterskich pisanych na wydziałach prawa kanonicznego. Wyrok wydany przez papieża Franciszka wpisuje się zatem w praktykę komentatorską. Jego znaczenie jest nieprzecenione, gdyż jest to pierwszy opublikowany wyrok wydany w oparciu o proces skrócony przed biskupem, z którym miałem okazję się zapoznać. Nie napotkałem dotychczas w polskiej literaturze podobnych publikacji ${ }^{6}$. Być może jest to spowodowane małą ilością wydanych w ten sposób wyroków, chociaż praktyka jest już kilkuletnia. Wydany przez Franciszka wyrok może wpłynąć na zwiększenie się tej praktyki w Kościołach partykularnych. Z tego też powodu nie traktuję go jako

3 P.V. Pinto, Małżeństwo i rodzina na synodalnej ścieżce papieża Franciszka, s. 10.

${ }^{4} \mathrm{~Np}$. opracowania W. Góralskiego zatytułowane Matrimonium facit consesnus. Z orzecznictwa Trybunału Roty Rzymskiej w sprawach o stwierdzenie nieważności małżeństwa rozpoznanych z tytułów dotyczacych zgody małżeńskiej, które ukazały się w trzech tomach (Warszawa, 2000; Płock, t. 2, 2014; t. 3, 2018, Pelplin 2020).

5 Np. K. Karsten, Orzeczenie nieważności małżeństwa. Aplikacja kan. 1095 nr 3 w wyrokach coram Sobański, Kraków 2017.

${ }^{6} \mathrm{~W}$ publikacjach zagranicznych przykład takiej praktyki stanowi wyrok coram Vescovo di Orvietto-Todi, Sent. in procesu breviore 16/5/2006, w: Quaderni dello Studio Rotale 23 (2016), s. 155-163. 
wyrok przykładowy tylko dlatego, że został wydany przez Franciszka. Nie tylko o autora wyroku tu chodzi, ale o pewną praktykę, którą sam pomysłodawca wciela w życie niejako zapraszając do skuteczniejszych form jej realizacji o ile okoliczności osób i faktów na to pozwalają. Nieznaczna dotychczas ilość wydawanych w ten sposób wyroków może mieć za przyczynę brak jednoznacznych przesłanek pozwalających na rozpoznanie sprawy przed biskupem czy też niemożliwość osiągnięcia wyraźnej zgody przez drugą stronę, co wskazywałoby jednocześnie na istniejące zawiłości sytuacji małżeńskich. W takich sytuacjach drogą wyjścia jest jedynie proces zwykły o stwierdzenie nieważności małżeństwa.

\section{Biskup diecezjalny jako sędzia i pasterz}

Franciszek jako biskup diecezji rzymskiej wydając wyrok w formie procesu skróconego przed biskupem skorzystał z prerogatyw przysługujących mu na mocy motu proprio Mitis Iudex Dominus Iesus $^{8}$. Postanowienia najwyższego prawodawcy w Kościele mają swoją głęboko eklezjologiczną podstawę. Papież jest bowiem najwyższym prawodawcą jako jednocześnie najwyższy nauczyciel wiary. Z postawy świadka wiary wynikają także jej prawne konsekwencje w postaci stanowionych norm, które są niczym innym jak prawnym wymiarem wiary Kościoła. Papież jest najpierw rzeczywistością teologalną i eklezjologiczną, a następnie prawną jako prawodawca nie tylko w Kościele, ale Kościoła. W tym kontekście należy zatem umieścić papieskie postanowienia dotyczące reformy procesu małżeńskiego oraz naturę procesu skróconego dokonywanego przed biskupem diecezjalnym. Jego roli w procesach małżeńskich nie można ograniczać i rozumieć jedynie w kategoriach administratora sprawiedliwości w Kościele, ani sprowadzać do spełniania procesowych zadań

7 Kan. 1683.

${ }^{8}$ Kan. $1683,1^{0}$. 
i obowiązków nałożonych prawem kościelnym . Biskup diecezjalny „osobiście w swoim Kościele, w którym jest ustanowiony pasterzem i głową, tym samym jest sędzią wobec wiernych, którzy zostali mu powierzeni”"10. Z jego związku z Kościołem, o którego troska została mu powierzona wynika aequa restitutio iustitiae, a „posługa sprawiedliwości jest częścią zasadniczą duszpasterskiej misji Kościoła, który szuka dobra osób"11. Z tego też powodu biskup nie może pozostawić „całkowicie funkcji sądowniczej w sprawach małżeńskich urzędom kurialnym"12, ani delegować swojej osobistej władzy sądowniczej, którą posiada na mocy konsekracji biskupiej. Franciszek wyraźnie wskazuje w MIDI, że istnieje równowaga w podziale ról pomiędzy biskupem diecezjalnym a wikariuszem sądowym, który wraz z biskupem stanowi jeden trybunał. Wikariusz sądowy działa zawsze w zależności od biskupa i nigdy nie zaciemnia jego osobistej władzy.

Osoba biskupa diecezjalnego jako sędziego spełnia ponadto inną, ważną rolę, której nikt poza nim nie może spełnić. Podkreśla to Franciszek w kontekście ewentualnych procesów skróconych o nieważność małżeństwa, gdyby miały się one dokonywać poza osobą biskupa diecezjalnego ${ }^{13}$. Zwraca uwagę, że osoba biskupa diecezjalnego w procesie skróconym stoi również na straży zasady nierozerwalności małżeństwa, która może być w takim procesie zagrożona. Szczególną rolę biskupa diecezjalnego papież uzasadnia charakterem relacyjności jaka istnieje pomiędzy papieżem i biskupami na wzór relacji początkowej pomiędzy Piotrem i Apostołami. Teologiczno - eklezjologiczne podłoże papieskiej reformy procesu małżeńskiego ujawnia głębszy sens

9 T. Rozkrut, Odpowiedzialność biskupa diecezjalnego, metropolity oraz konferencji biskupów za współczesny proces małżński (spostrzeżenia na marginesie motu proprio „Mitis Iudex Dominus Iesus” papieża Franciszka z 15 sierpnia 2015 r.), w: Proces małżenski według motu proprio Mitis Iudex Dominus Iesus, red. J. KRAJCZYŃski, Płock, 2015, s. 41-47.

10 Midi, Preambuła, n. III.

11 Franciszek, Lettera al Magnifico Rettore della Pontificia Università Cattolica Argentina, w: Quaderni dello Studio Rotale 22 (2015), s. 50.

12 Midi, Preambuła, n. III.

13 Midi, Preambuła, n. IV. 
pasterskiej posługi biskupów powiązanej z ochroną nierozerwalności małżeństwa. Wynika to $\mathrm{z}$ faktu, że biskupi wraz z papieżem uczestniczą „w misji Kościoła, polegającej na ochronie jedności w wierze i w dyscyplinie dotyczącej małżeństwa"14. Eklezjologiczny znak biskupa jako figury urzeczywistniającej jedność Kościoła powszechnego z Kościołem partykularnym jest jednocześnie gwarancją przed nadużyciami. Tych bowiem nie można wykluczyć jako czynników ludzkich. Można je jednak wyeliminować, jeśli wykonywanie władzy biskupiej, w tej sytuacji władzy sądowniczej, będzie dokonywało się w postawie zawsze zwróconej ku temu, „który jako Głowa Kościoła, jest pierwszym i fundamentalnym przykładem"15.

\section{Autor wyroku}

Papieski wyrok, jak podkreślił dziekan Roty Rzymskiej P.V. Pinto, należy traktować jako wyrok przykładowy. Nie jest on z pewnością takim ze względu na jego treść i uzasadnienie, gdyż one zawarte są we wszystkich wyrokach wydawanych w sprawach o stwierdzenie nieważności małżeństwa opartych na obowiązujących przepisach prawnych i modelowym orzecznictwie Roty Rzymskiej. Przykładowego charakteru wyroku należy doszukiwać się w zachowaniu papieża aplikującego nie tylko obowiązujące przepisy prawa, lecz przede wszystkim ucieleśniającego postawę służby biskupa względem powierzonych jego trosce duszpasterskiej wiernych. Od początku pontyfikatu papieża Franciszka centralne miejsce jego posługi zajmuje troska o biednych i ubogich. Do nich zaliczają się również ci, którzy doświadczyli rozpadu życia małżeńskiego oraz inni żyjący w stanie nowych związków, które nie odpowiadają zamysłowi Boga względem związku małżeńskiego. ${ }^{16} \mathrm{~W}$ swojej sytuacji są oni dalecy od możliwości pełnego przylgnięcia do Chrystusa w Eucharystii. Postawa służby, którą Franciszek objawia na wiele sposobów realizuje

\footnotetext{
14 Midi, Preambuła.

15 P.V. Pinto, Małżeństwo i rodzina na synodalnej ścieżce papieża Franciszka, s. 25.

16 O tym zamyśle pisał Franciszek w Amoris laetitia, rozdział I.
} 
się również przez wyjście naprzeciw możliwościom szybszego naprawienia nieprawidłowości, które pojawiły się w życiu osób wierzących.

Przykład Franciszka jest również zachętą skierowaną do biskupów do podejmowania takiego charakteru służby we własnych Kościołach partykularnych. Jest zachętą opartą na ścisłych relacjach pomiędzy biskupami diecezjalnymi a biskupem Rzymu, których fundament opiera się na papieskim zaufaniu i przekonaniu o obecności Chrystusa w swoim Kościele pochylającego się nad każdym ubogim oraz na inspirującym biskupów działaniu Ducha w ich duszpasterskiej działalności. Odczytuję to również jako pewną formę oddalenia pokusy myślenia, że działalność papieża pozostaje jego prerogatywą, gdyż papież ma prawo „sądzić inne sprawy, które sam wezwał przed swój sąd" ${ }^{17}$ oraz lęku przed podejmowaniem osobistej decyzji. Papież poprzez normatywne uregulowanie rzeczywistości teologalnej zaprasza biskupów do włączenia się w jego praktyczne działanie na rzecz zbawienia rodziny.

Papież Franciszek wydał wyrok stwierdzający nieważność małżeństwa nie z powodu prerogatyw papieskich dotyczących możliwości rozsądzania każdej sprawy. Podstawą przeprowadzenia procesu skróconego przed biskupem była jego osoba jako biskupa diecezji rzymskiej. W tytule wyroku zawarta została informacja stwierdzająca, że jego autorem jest Franciscus Urbis Episcopus. Franciszek jest biskupem kompetentnym do wydania wyroku w procesie skróconym ze względu na właściwości trybunału mogącego przyjąć i rozpatrzyć sprawę o nieważność małżeństwa. Małżeństwo, którego nieważność została zawyrokowana zostało zawarte w Rzymie w 1983 r. Trybunałem kompetentnym do przyjęcia sprawy był zatem trybunał diecezji rzymskiej. Jedyną osobą uprawnioną do wydania wyroku był jej biskup, który musiał wyrokować osobiście. Żadna inna osoba, w tym wikariusz sądowy, nie są bowiem uprawnieni do wyrokowania w tej formie procesu.

Interesującym wątkiem procesu przed biskupem diecezji rzymskiej jest udział osób biorących udział w instrukcji sprawy, czyli faktycznie

17 Kan. $1405 \$ 1,4^{0}$; kan. 1442. 
osądzających możliwość rozpatrzenia prośby o stwierdzenie nieważności małżeństwa coram episcopo. Decyzja ta należy do wikariusza sądowego ${ }^{18}$. W omawianej sytuacji osobami, które występują w fazie instrukcji sprawy są dziekan Roty Rzymskiej oraz jeden z jej sędziów w roli instruktora sprawy. W wyroku wyraźnie zostało stwierdzone, że Franciszek wydając wyrok zasięgnął opinii zarówno dziekana Roty jak również instruktora sprawy ${ }^{19}$. Rodzi się nieuchronne pytanie dotyczące tego, kto przedstawił biskupowi Rzymu prośbę o rozpatrzenie sprawy na drodze procesu skróconego. Jeśli proces był złożony do trybunału diecezjalnego powinien uczynić to wikariusz sądowy. Tak mogło się wydarzyć, o czym jednak nie została uczyniona wzmianka w wyroku. Skąd zatem uczestnictwo sędziów z Roty Rzymskiej? Jeśli są członkami trybunału diecezjalnego, to przysługuje im uczestnictwo w procesie w jego fazie instrukcyjnej. Do wikariusza sądowego należy powołanie instruktora i asesora.

Uczestnictwo sędziów rotalnych może jednak sugerować, że sprawa została wprowadzona bezpośrednio do Roty Rzymskiej. Taka możliwość istnieje w oparciu o kan. $1417 \$ 1$ i $1444 \$ 2$.

Nie podlega żadnej wątpliwości, że wyrok został wydany przez samego papieża, o czym świadczy jego podpis na wyroku oraz używanie w treści wyroku gramatycznych form odwołujących się bezpośrednio do jego osoby.

\section{Aspekty procesowe papieskiego wyroku}

Warunkiem wstępnym rozpoczęcia procesu jest żądanie „zgłoszone przez obydwoje małżonków lub przez jednego z nich za zgodą drugiego" ${ }^{20}$. Z wyroku papieskiego wynika, że prośba została złożona przez stronę powodową (kobieta). Nie ma w nim jednak wyraźnej wzmianki o uzyskaniu zgody drugiej strony. Co do tej nie powinno być żadnych wątpliwości. W przeciwnym razie kwestia nie trafiłaby do

\footnotetext{
18 Kan. $1676 \$ 2$.

19 Sent., n. 2.

20 Kan. $1683,1^{0}$.
} 
Franciszka z prośbą o wydanie wyroku stwierdzającego nieważność małżeństwa. Sam papież wspomina w sentencji wyrokowej, że wydaje ją peractis de iure peragendis ${ }^{21}$. Okoliczności uzyskania zgody przedstawia P.V. Pinto pisząc, że pozwany wiedział o pozwie, który złożyła kobieta i podpisał się pod petycją deklaracji nieważności jednocześnie prosząc o zastosowanie procesu skróconego ${ }^{22}$. Podstawowy warunek został spełniony. Przykład zredagowania wyroku bez wskazania na zgodę drugiej strony jest jednocześnie wskazówką dla sposobów redagowania wyroków wydawanych przez innych biskupów diecezjalnych. Nie wszystkie elementy potwierdzające zasadność prowadzenia procesu przed biskupem muszą znajdować się w treści sentencji wyrokowej, co sprzyja zwięzłej redakcji i skupieniu się na tym, co istotne dla samego wyroku.

Kolejnym elementem prawidłowego sposobu postępowania w procesie przed biskupem jest udział obrońcy węzła małżeńskiego w fazie instrukcji sprawy. W treści wyroku jego obecność została wyraźnie stwierdzona. Był nim jeden z adwokatów Roty Rzymskiej. W wyroku nie ma jednak żadnego odniesienia do uwag przez niego poczynionych.

$\mathrm{Na}$ uwagę zasługuje również czas trwania całej sprawy, od momentu wpłynięcia skargi powodowej do wydania sentencji. Zgodnie z obowiązującymi przepisami wikariuszowi sądowemu od momentu określenia formuły wątpliwości, wraz z którą ustanawia instruktora i asesora przysługuje prawo zobowiązania osób odpowiedzialnych za instrukcję sprawy do jej przeprowadzenia na odpowiednim posiedzeniu w ciągu trzydziestu dni ${ }^{23}$. Po zebraniu dowodów przez instruktora w tym okresie powinien on sam wyznaczyć termin piętnastu dni na przedstawienie uwag na korzyść węzła oraz pism obroń$\mathrm{czych}^{24}$. W analizowanym dekrecie nie ma wzmianki o czynnościach

\footnotetext{
21 Sent., n.2.

22 P.V. Pinto, Małżeństwo i rodzina na synodalnej ścieżce papieża Franciszka, s. 211-212.

23 Kan. 1685.

24 Kan. 1686.
} 
wikariusza sądowego od momentu wpłynięcia skargi do wydania dekretu o formule wątpliwości i jednoczesnym ustanowieniu instruktora i asesora. Została podana data wpłynięcia skargi powodowej (12.06.2017) i data wydania sentencji pro nulitate (13.07.2017). Nie wydaje się jednak, by wikariusz sądowy w rozpatrywanym przypadku potrzebował więcej czasu pozwalającego mu na określenie formuły wątpliwości ze względu na podpisanie skargi przez obie strony, z której jasno wynikają podstawy nieważności małżeństwa. Jednak przed sformułowaniem wątpliwości procesowej powinien wysłuchać stanowiska obrońcy węzła małżeńskiego ${ }^{25}$, któremu na wykonanie swojego zadania przysługuje termin $15 \mathrm{dni}^{26}$. Biorąc pod uwagę czas przeznaczony na podjęcie działalności procesowej przez obrońcę, warto zauważyć, że wikariusz sądowy działał bardzo szybko. W ciągu piętnastu dni (wszystko trwało miesiąc) wikariusz przyjął skargę powodową, dokonał czynności przewidzianych przed dekretem ustalenia formuły sporu oraz miała miejsce instrukcja sprawy na, zgodnie z prawem, przewidzianym i zwołanym przez instruktora posiedzeniu. Opisywana sytuacja wydania wyroku przed biskupem została przeprowadzona w iście ekspresowym tempie. Czas z maksymalnie liczonego okresu 45 dni od momentu sformułowania wątpliwości do przedstawienia sprawy do wyrokowania biskupowi skrócił się do miesiąca od momentu wpłynięcia skargi powodowej do wydania wyroku. Czas trwania całego procesu potwierdził tym samym jego istotę wyrażoną w nazwie processus brevior.

Elementem pozwalającym na przedstawienie sprawy biskupowi w procesie skróconym „są okoliczności dotyczące faktów i osób, poparte zeznaniami lub dokumentami, które nie wymagają przeprowadzenia dokładniejszego badania oraz w sposób oczywisty wskazują na nieważność"27. Wskazane przez Franciszka w MIDI okoliczności nie stanowią przyczyn nieważności małżeństwa zgodnie z istniejącymi tytułami nieważności, lecz są jedynie symptomami, poszlakami

\footnotetext{
25 Pominięcie działania obrońcy powoduje nieważność akt., kan. 1433.

26 Kan. $1676 \$ 1$.

27 Kan. 1683, $2^{0}$.
} 
rzeczywistych tytułów. ${ }^{28}$ Korelacja pomiędzy nimi a właściwymi tytułami musi opierać się na faktycznym ich związku, który na dodatek nie będzie wymagał przedłużonego okresu ich udowodnienia. Stan faktyczny okoliczności nie zawsze może odpowiadać istniejącym tytułom nieważności albo faktycznie do nich prowadzić. Dlatego też wskazanie na związek pomiędzy okolicznościami a tytułami nieważności małżeństwa przechodzi podwójną weryfikację. Pierwszej z nich dokonuje wikariusz sądowy decydując na przekazanie sprawy do rozpatrzenia wobec biskupa w procesie skróconym, a drugiej sam biskup w procesie logicznego wnioskowania i konstruowania wniosków prowadzących do osiągnięcia stanu pewności moralnej. W papieskiej sentencji okolicznością wskazującą na możliwość przeprowadzenia procesu skróconego był krótki okres pożycia małżeńskiego stron, do oceny którego wystarczyło stwierdzenie czterech miesięcy pożycia małżeńskiego do momentu odejścia kobiety ${ }^{29}$. Dosyć enigmatyczne i niezbyt precyzyjne określenie krótkości (brevitas) ${ }^{30}$ pożycia małżeńskiego nabiera swojego znaczenia poprzez odniesienie do okoliczności, które do takiego stanu doprowadziły oraz sądowego doświadczenia sugerującego ${ }^{31}$, że krótkotrwały okres pożycia małżeńskiego może być konsekwencją braku faktycznych predyspozycji do zaistnienia związku małżeńskiego. Takimi okolicznościami, które zostały niejako potwierdzone przez krótki okres pożycia małżeńskiego w omawianym wyroku papieża Franciszka są: decyzja powódki o małżeństwie z mężczyzną podjęta pod dużym wpływem woli jej

\footnotetext{
28 Midi, Zasady proceduralne w sprawach o stwierdzenie nieważności małżeństwa, art. $14 \$ 1$.

29 Sent., n. 7.

30 Praktyczny komentarz do Listu apostolskiego motu proprio Mitis Iudex Dominus Iesus papieża Franciszka, red. P. Skonieczny, Tarnów 2015, s. 196.

31 H. STAWNIAK, Okoliczności uzasadniajace proces małżeński przed biskupem: brak wiary, krótki czas pożycia matżeńskiego, aborcja, pozostawanie w relacji pozamatżeńskiej, w: T. Rozkrut (red.), Reforma procesowa papieża Franciszka - pierwsze doświadczenie. Materiały z ogólnopolskiego spotkania pracowników sądownictwa kościelnego w Gródku nad Dunajcem w dniach 12-13 czerwca 2017 roku, Tarnów 2018, s. 57.
} 
matki; stan zakochania powódki w momencie zawierania małżeństwa w innym mężczyźnie, który w momencie zawarcia przez nią małżeństwa odbywał służbę wojskową; trwanie w tym stanie zakochania przez okres małżeński; decyzja o opuszczeniu małżeństwa przez kobietę i związanie się z mężczyzną po zakończeniu przez niego służby wojskowej. Potwierdzeniem decyzji powódki chęci tworzenia rodziny z mężczyzną, w którym była zakochana jest związek cywilny trwający od 1985, w którym zrodziło się dwoje dzieci.

Wobec powyższych argumentów, potwierdzonych zgodą drugiej strony, został sformułowany tytuł nieważności małżeństwa: ob exslusum bonum sacramenti ex parte mulieris actricis ${ }^{32}$.

\section{Aspekty materialne papieskiego wyroku}

1. Tytuł nieważności. W skardze skierowanej do trybunału kościelnego, której fragmenty poznajemy w części uzasadniającej stwierdzenie nieważności małżeństwa ${ }^{33}$, powódka napisała o swoich wątpliwościach dotyczących małżeństwa, jej niechęci wobec drugiej strony, które wraz z innymi argumentami były podstawą ustalenia formuły wątpliwości oraz decyzji wykluczającej potomstwo w związku. Wykluczenie potomstwa przez kobietę nie zostało włączone do tytułów nieważności małżeństwa stron. Sytuacja taka i decyzja o treści formuły wątpliwości mogły być podyktowane brakiem przekonywujących argumentów zawartych w skardze powodowej. Mogły również spotkać się ze sprzeciwem drugiej strony, dla której decyzja o wykluczeniu potomstwa nie była znana lub przekonywująca, a w konsekwencji nie została przez nią potwierdzona.

Powyższa sytuacja może wpłynąć w praktyce na sposób formułowania tytułów nieważności małżeństwa w procesie skróconym. Komentatorzy obowiązujących przepisów zwracają uwagę, że zgoda małżonków nie powinna dotyczyć jedynie pragnienia wszczęcia procesu przed biskupem, lecz również tytułów nieważności, by w ten

\footnotetext{
32 Sent., n. 2.

33 Sent., n. 6.
} 
sposób ułatwić samą procedurę dochodzenia do pewności opierając się na pewnych środkach dowodowych oraz nie zatracić specyficznej cechy procesu, jaką jest szybkość podjęcia decyzji. Dodatkową kwestią jest ilość sformułowanych tytułów. Nie wydaje mi się, że należałoby się ograniczać jedynie do jednego tytułu. Sformułowanie dwóch lub ewentualnie więcej tytułów nieważności nie oznacza bowiem, że w rzeczywistości nie zaistniały sytuacje prowadzące do ich określenia i że są trudne do udowodnienia. Biskup może osiągnąć pewność moralną co do wszystkich przedstawionych mu tytułów. Jeśliby biskup osiągnął stan pewności moralnej co do jednego tytułu, przy braku takowej w odniesieniu do drugiego tytułu orzeczenie nieważności małżeństwa skutkowałoby w swojej mocy. Pozostaje jednak sprawa odpowiedzi na drugi czy kolejny tytuł. Biskup może bowiem stwierdzić jedynie nieważność małżeństwa z konkretnego tytułu. Nie jest w jego prerogatywach stwierdzenie nieważności małżeństwa z tytułów, co do których nie osiągnął pewności moralnej. Jej brak powoduje odesłanie sprawy do rozpatrzenia w trybie procesu zwykłego. W sytuacji, w której biskup decydowałby o nieważności małżeństwa $\mathrm{z}$ jednego tytułu, mając wątpliwości co do drugiego lub pozostałych, powinien odesłać sprawę. Nie może opowiedzieć się bowiem za ważnością małżeństwa $\mathrm{z}$ jakiegoś tytułu. Pytanie postawione w tytule nieważności powinno uzyskać odpowiedź sędziowską. Gdyby do takiej sytuacji doszło, stanowiłaby ona pewną niezręczność. Sąd musiałby odpowiadać na pytanie dotyczące nieważności małżeństwa $\mathrm{z}$ innego tytułu niż ten, z którego nieważność orzekł wcześniej biskup. Sam również biskup znalazłby się w trudnej sytuacji, gdyby doszedł do przekonania o nieważności małżeństwa z jednego tytułu, a nie z pozostałych. W takiej sytuacji rzeczą pożądaną byłoby sformułowanie jednego tytułu małżeństwa i przedstawienia sprawy biskupowi w procesie skróconym. Wymaga to jednak zaangażowania w ocenie sytuacji wikariusza sądowego decydującego o trybie rozpatrywania sprawy. 
2. Argumentacja in iure ${ }^{34}$. Czytając uzasadnienie wyroku w części in iure można dostrzec dwie linie argumentacji. Jedna odnosi się do władzy biskupa i jego prerogatyw wynikających z posiadanej przez niego władzy sędziowskiej. Druga natomiast dotyczy samego rozpatrywanego przypadku.

W pierwszej części argumentacji ${ }^{35}$ papież przytacza postanowienia zawarte w MIDI dotyczące pełnej i całkowitej, osobistej i bezpośredniej władzy biskupa w sprawach małżeńskich oraz klarowności sytuacji, która doprowadziła do nieważności małżeństwa. Obie przesłanki są podstawą wydania wyroku przez biskupa w procesie skróconym. W dalszej części swojej argumentacji przywołuje przemówienie Jana Pawła II do Roty Rzymskiej z 2005 r., w którym papież wskazuje, że proces o stwierdzenie nieważności małżeństwa ma na celu poszukiwanie prawdy obiektywnej, co spoczywa przede wszystkim na biskupach, którzy są sędziami z prawa Bożego we wspólnotach, którym przewodzą. Z tego też powodu nie powinni uważać spraw o stwierdzenie nieważności małżeństwa jako kwestii o charakterze jedynie technicznym, powierzając je całkowicie swoim wikariuszom sądowym. W dalszej części przechodzi do ukazania współczesnej sytuacji, w której osoby zawierające małżeństwo nie kierują się prawdą o małżeństwie w zamyśle Boga. Przywołuje słowa papieża Benedykta XVI skierowane do Roty Rzymskiej w 2013 r. Papież zwraca uwagę, że zamknięcie się na prawdę o małżeństwie zagraża ważności paktu małżeńskiego o ile odrzuca się jego podstawowy element, jakim jest nierozerwalność lub pozostałe elementy i przymioty małżeństwa. Odwołując się do prawdy o małżeństwie przypomnianej przez swego poprzednika Franciszek przechodzi do dalszej części argumentacji wskazując na to, o czym pisał w Evangelii gaudium (n. 64) na temat kontekstu wychowania chrześcijańskiego oraz intencji z jakimi osoby zawierają małżeństwo, o czym wspomniał w swoim przemówieniu do Roty Rzymskiej w 2017 r.

\footnotetext{
34 Sent., nn. 3-5.

35 Sent., nn. 3-4.
} 
Po przypomnieniu podstaw teologicznych dotyczących chrześcijańskiego małżeństwa, podstaw i sposobów wykonywania władzy biskupiej oraz sytuacji osób wchodzących w związki małżeńskie przesiąkniętych współczesną mentalnością negacji ich trwałości, papież powołuje się, w drugiej części swej argumentacji in iure ${ }^{36}$, na wydane przez siebie Zasady proceduralne w sprawach o stwierdzenie nieważności małżeństwa (art. $14 \$ 1$ ) wskazując, że istniały podstawy do przeprowadzenia procesu o stwierdzenie nieważności małżeństwa w procesie skróconym przed biskupem. Do tych podstaw zalicza: krótkotrwały okres wspólnoty małżeńskiej, stan zakochania kobiety w innym mężczyźnie przed i w trakcie trwania małżeństwa, które wskazują na brak zgody na małżeństwo z jej strony.

3. Argumentacja in facto $^{37}$. Argumentacja papieska jest krótka i odzwierciedlająca sposób dochodzenia i dowodzenia do stwierdzenia nieważności w przypadkach symulacji częściowej, w tym wykluczenia nierozerwalności małżeństwa. Franciszek zestawia przyczyny symulacji (causa simulandi) z przyczyną zawarcia małżeństwa (causa contrahendi) wskazując argumenty, w których przyczyna symulacji przeważyła nad przyczyną zawarcia małżeństwa. Analizuje i przytacza argumenty kobiety, które doprowadziły ją do symulacji zgody małżeńskiej.

$\mathrm{Na}$ pierwszym miejscu wskazuje na argumenty, które nie są wystarczające do stwierdzenia prawdziwej chęci symulacji, aczkolwiek mogą być traktowane jako przyczyny dalsze symulacji. Kobieta bowiem wskazała w skardze powodowej na swoją niechęć do osoby małżonka w związku z różniącymi strony poglądami na życie oraz jego przytłaczającym sposobem bycia wynikającym z jego usposobienia. Z tego powodu pojawiały się u niej obawy co do przyszłości ich wspólnego życia, wątpliwości dotyczące zachowania małżonka względem niej w przyszłości. W dalszej części uzasadnienia Franciszek wskazuje na właściwe elementy będące przyczyną bliższą symulacji: relacja uczuciowa $\mathrm{z}$ innym mężczyzną, który odbywał służbę

\footnotetext{
36 Sent., n. 5.

37 Sent., nn. 7-8.
} 
wojskową. Będąc stale zakochana w innym mężczyźnie podjęła decyzję o małżeństwie na skutek posłuszeństwa swojej matce. Podczas małżeństwa, w którym strony mieszkały razem przez jedynie cztery miesiące, kobieta nadal myślała o innym mężczyźnie i żyła miłością do niego. O tej miłości świadczy to, że opuściła wspólnotę małżeńską i zawarła z nim związek cywilny, gdy ten odszedł z wojska. Razem stworzyli stabilną rodzinę z dwójką dzieci.

Jako causa contrahendi Franciszek powołuje się na motywację zawarcia małżeństwa, którą kobieta przedstawiła w skardze powodowej. Napisała w niej, że zawierała małżeństwo myśląc, że różnice istniejące pomiędzy stronami zostaną rozwiązane przez zawarcie małżeństwa. Z twierdzeń kobiety wynika, że przyczyną zawarcia małżeństwa nie była rzeczywista chęć stworzenia związku małżeńskiego jako przymierza całego życia, lecz jedynie jej pragnienie wolności, które popchnęło ją do życia małżeńskiego, którego chciała doświadczyć. Owo jedynie doświadczenie jako motyw zawarcia małżeństwa pozostało w konfrontacji z miłością do innego mężczyzny jako przyczyną symulacji. Kobieta zawierając małżeństwo nie wchodziła w trwały związek małżeński, gdyż to nie było jej celem. W tej sytuacji papież wymienia wszystkie okoliczności z życia kobiety, z jej przekonaniami, racjami zawarcia małżeństwa i przyczynami symulacji, które doprowadziły go do moralnej pewności, że kobieta zawierając małżeństwo wykluczyła bonum sacramenti, a tym samym nieważnie wyraziła zgodę małżeńską.

\section{Uwagi do wyroku}

Wyrok wydany przez Franciszka dziekan Roty Rzymskiej określił jako przykładowy. Z pewnością za taki uchodzi jako wyrok wydany przez papieża, czego papieże nie byli zwykli czynić od wieków. Przykładowy charakter tego wyroku można dostrzec na dwóch płaszczyznach: prawnej i teologicznej.

W płaszczyźnie prawnej nietrudno zauważyć, że wyrok Franciszka jest zastosowaniem wydanych przez niego norm dotyczących procesu skróconego przed biskupem. Na uwagę zasługuje sam fakt 
urzeczywistnienia zasady szybkości procesowej, która stoi u podstaw tej formy procesu. Interesująca i godna polecenia jest również redakcja wyroku. Nie ma w nim rzeczy zbędnych dla zrozumienia przeprowadzonej argumentacji. Brak w nim, co często się pojawia w redakcjach wyroków sądowych, obszernych cytatów fragmentów skargi powodowej, czy też treści przeprowadzonej instrukcji sprawy. Wyrok jest krótki i rzeczowy, skoncentrowany wokół tego, co istotne. Uważam to za dobry przykład. Treść skargi oraz treści zeznań i instrukcji są bowiem zawarte w aktach sprawy. Uważam jednak, że dla redakcji przyszłych wyroków przydatne byłoby określenie w części wyroku dotyczącej przebiegu sprawy (facti species) określenie trybunału, do którego wyrok wpłynął, podania informacji dotyczących decyzji wikariusza sądowego o trybie procesu skróconego przed biskupem oraz informacji dotyczących instrukcji sprawy (kto brał w niej udział, jakie dokumenty zostały zebrane, które wpłynęły na podjęcie decyzji o procesie przed biskupem).

Wyrok Franciszka ma jednak moim zdaniem znaczenie w warstwie teologicznej, która powinna odzwierciedlać się w powszechnej praktyce sądowniczej. Franciszek wydając wyrok jest przykładem służebnej postawy biskupa względem osób „pokrzywdzonych w małżeństwie, które mogą oczekiwać na sprawiedliwość"38. Pochylając się nad konkretną sytuacją rozpadu związku małżeńskiego papież jest przykładem dla tych, którzy stoją na czele chrześcijańskich wspólnot, ucieleśniając w sobie osobę Chrystusa - najwyższego pasterza, jest przykładem osobistego zaangażowania i poszukiwania dobra dusz. Działalność Franciszka należy dostrzegać również w perspektywie jedności kolegium biskupiego jako zachęcającego braci biskupów do dzielenia z nim drogi synodalnej Kościoła i odwagi w podejmowaniu decyzji w pełnym zaufaniu do prawdy, której biskupi są strażnikami.

Jest jeszcze jeden element godzien uwagi. Dotyczy on ścisłego związku teologii i prawa w służbie człowiekowi. Prawo kościelne nie jest bowiem czymś, co znajduje się w kontrapozycji do wiary, ale tworzy przestrzeń dla jej urzeczywistnienia. Dostrzegając znaczenie

38 P.V. Pinto, Małżeństwo i rodzina na synodalnej ścieżce papieża Franciszka, s. 207. 
wymiaru teologicznego i prawnego obecnych w papieskim wyroku można odwołać się do słów dziekana Roty Rzymskiej, który stwierdził, że „poprzez ten historyczny gest [Franciszek] dał najbardziej wiarygodny komentarz do prawa" ${ }^{39}$.

\section{Pope Francis as a Judge in the Process of Nullity of Marriage Summary}

The subject of the study is the analysis of the sentence issued by Pope Francis in the briefer matrimonial process before the bishop. The author discusses its subsequent stages, paying attention to those legal and theological elements that may become useful in the application of norms by bishops.

Słowa kluczowe: Franciszek, proces skrócony przed biskupem, wyrok

Key words: Francis, briefer matrimonial process before the bishop, sentence

\section{Nota o autorze}

O. Tomasz Gałkowski CP - kapłan z zakonu pasjonistów, doktor habilitowany nauk prawnych w zakresie prawa kanonicznego, profesor nadzwyczajny Uniwersytetu Kardynała Stefana Wyszyńskiego w Warszawie, sędzia Trybunału Metropolitalnego w Łodzi.

39 P.V. Pinto, Małżeństwo i rodzina na synodalnej ściė̇ce papieża Franciszka, s. 215 . 